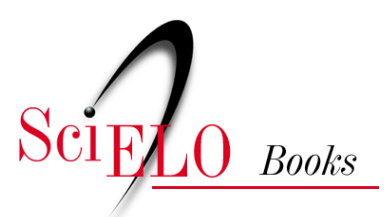

\title{
Reflexões \\ Não acabem com nossa internet
}

\author{
Nelson De Luca Pretto
}

PRETTO, N.D.L. Não acabem com nossa internet. In: Educações, culturas e hackers: escritos e reflexões [online]. Salvador: EDUFBA, 2017, pp. 96. ISBN: 978-85-232-2019-8.

https://doi.org/10.7476/9788523220198.0009.

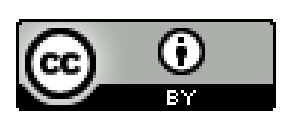

All the contents of this work, except where otherwise noted, is licensed under a Creative Commons Attribution $\underline{4.0 \text { International license. }}$

Todo o conteúdo deste trabalho, exceto quando houver ressalva, é publicado sob a licença Creative Commons Atribição 4.0.

Todo el contenido de esta obra, excepto donde se indique lo contrario, está bajo licencia de la licencia Creative Commons Reconocimento 4.0. 


\section{Não acabem com nossa internet}

Os ataques à internet são diários. As grandes corporações das telecomunicações - e não só elas - se articulam de forma intensa para impor seus modelos de negócios em todos os aspectos do sistema de comunicação mundial. Um sistema com potente evolução tecnológica e que, obviamente, exige investimentos. Mas não é possível que, em nome desses investimentos, que nem mesmo são claramente apresentados à população, essas empresas queiram transferir todo o custo para o cidadão.

A última investida das operadoras foi anunciar o fim da chamada internet ilimitada para as conexões fixas, derrubada temporariamente pelo pleno da Anatel, que contrariou a opinião do seu presidente ao vaticinar o "fim da internet ilimitada". Pior, ele ainda culpou os jovens ("deseducados") por jogarem online! A Anatel, que nasce como órgão regulador do sistema, há muito tempo tem representado com mais força as empresas de telecomunicações do que os cidadãos brasileiros. As reações a mais essa investida das operadoras foi seguida de imediata e contundente reação dos órgãos de defesa do consumidor, de ativistas da cultura digital, $\mathrm{OAB}$ e todos nós, cidadãos que não aceitamos essas mudanças que sempre nos trazem prejuízos.

Caso seja imposto esse limite, boa parte dos atuais consumidores que assiste a filmes e vídeos, fala e escreve livremente, terminará sua "cota" mensal em apenas um ou dois dias. Os movimentos sociais, já fortemente articulados pelas redes, sofrerão profundo golpe ao sentir na pele a limitação do uso, em função do aumento dos custos de conexão.

Já imaginamos a negativa de fornecimento de senhas wifi nas casas e espaços públicos, estimulando o crescimento de comportamentos avessos à colaboração e à camaradagem, evidenciando mais ainda posturas individualistas e egoístas, já preconizados por uma sociedade do consumo generalizado, que pouco pensa no coletivo.

Nesses tempos de obscurantismo, todo o cuidado é pouco, pois os retrocessos aparecem e aparecerão em todas as áreas. 